\title{
Article
}

https://doi.org/10.11646/phytotaxa.360.3.9

\section{A new combination in Leontodon (Asteraceae, Cichorieae)}

\section{FABIO CONTI}

Scuola di Bioscienze e Medicina Veterinaria, Università di Camerino - Centro Ricerche Floristiche dell'Appennino, Parco Nazionale del Gran Sasso e Monti della Laga, S. Colombo, 67021 Barisciano (L’Aquila)

\begin{abstract}
A new species-level combination, Leontodon albanicus comb. \& stat. nov., is proposed on the basis of a subspecies described from Albania. The species is reported here as new to Greece. The variability of the taxon has been examined and a new morphological description has been provided. Its relationship with the closest taxa is also discussed.
\end{abstract}

Key words: Albania, endemic, vascular plants

\section{Introduction}

During two journeys to southern Albania undertaken in 2012 and 2015 I collected some specimens of Leontodon Linnaeus (1753: 798) belonging to Leontodon sect. Asterothrix (Cassini 1827: 434) Ball (1850: 11). This section occurs throughout the Mediterranean, from the Iberian Peninsula to southwestern Asia (Meusel \& Jäger 1992) and is usually characterised by 3 - to several-fid or stellate stalked hairs on leaves and phyllaries, and all achenes with pappus bristles. According to Zidorn (2012), this is the most complex group of the genus, particularly the structure of L. crispus Villars (1779: 34) s.l is controversial. Samuel et al. (2006) analyzed the genus from a molecular phylogenetical point of view. A core group of species with $2 \mathrm{n}=8$ inside $L$. sect. Asterothrix is well supported as a monophyletic unit. It includes taxa often treated at the level of subspecies (e.g., Finch \& Sell 1976), which partly have quite divergent DNA sequences.

Most closely related to my Albanian specimens is the group of Leontodon incanus; according to Pittoni (1974), it comprises: L. incanus (Linnaeus 1753: 799) Schrank (1786: 14), L. tenuiflorus (Gaudin 1830: 362) Reichenbach (1832: 853), L. intermedius (Fiori in Fiori \& Béguinot 1904: 401) Huter, Porta \& Rigo in Huter (1907: 116), L. hellenicus Phitos (1966: 272), L. berinii (Bartling 1820: 345) Roth (1830: 1129), L. anomalus Ball (1850: 9).

Five taxa belonging to Leontodon are recognized in Albania according to Greuter (2006): L. biscutellifolius Candolle (1838: 103), L. crispus, L. hispidus subsp. hastilis (Linnaeus 1763: 1123) Corbière (1894: 370), L. saxatilis subsp. saxatilis, L. saxatilis subsp. rothii Maire in Jahandiez \& Maire (1934: 833) and L. tuberosus Linnaeus (1753: 799), while Barina (2017) reported seven species from the country: L. cichoraceus, L. crispus, L. hispidus, L. incanus, L. montanus, L. taraxacoides and L. tuberosus.

Meyer (2011) collected in Albania L. asperrimus (Willdenow 1803: 1507) Endlicher (1842: 415) (as L. crispus subsp. asperrimus) and L. hispidus subsp. hispidus, and described L. incanus subsp. albanicus Meyer (2011: 170).

In order to determine the collected Albanian specimens, they were compared with the taxa of $L$. incanus group. After this analysis they have been attributed to L. incanus subsp. albanicus. Meyer (2011) described this taxon without a detailed description but only with a short differential diagnosis based on sinuate leaves, pappus hairs denticulate and not plumose. Furthermore he reported that the leaf hairs are stellate bearing up to 7 branches.

Having observed significant differences mainly in the characters of leaf hairs (number of branches of stellate hairs), bract hairs and shape of leaves between this taxon and the other taxa in the L. incanus group, a new combination is proposed here. 


\section{Material and Methods}

This study is based mainly on my field surveys, analysis of relevant literature, and careful examination of herbarium specimens (including the original material of $L$. incanus subsp. albanicus and $L$. hellenicus) kept in APP, B, BP, JE, LD (acronyms follow Thiers 2018). The most useful characters that could be used in the morphological analysis in this group were: i) type of hairiness of bracts and leaves (Pittoni 1974); ii) shape of leaves (pers. obs.).

\section{Results}

A new population of Leontodon was found and identified as L. incanus subsp. albanicus. This taxon belongs to the $L$. incanus group. After morphological observations, L. incanus subsp. albanicus is found significantly different from $L$. incanus s.s. as well as from the other taxa included in the group, so I propose to treat it as a separate species within the L. incanus group. A new chorological datum from Greece is also provided here. According to the available specimens, this taxon is new to Greece.

The closest species (Table 1) are L. incanus, distributed in Central, South and Southeast Europe (Greuter 2006) and L. hellenicus, which is endemic to Greece (Phitos 1966). Leontodon albanicus differs from L. incanus by bracts with sparse to dense, flexuose, long stellate (2-8-fid) hairs, while in $L$. incanus hairs on bracts are sparse and similar to the leaf hairs; leaves are sinuate-dentate, with mainly (4-) 8 (-9)-fid longer stalked hairs, while $L$. incanus has leaves almost entire with (3-) 4-6-fid hairs (Zidorn 2012; pers. obs.). The number of branches of stellate hairs varies on the same leaf but it is important to consider the most common type, which is constant and diagnostic. Meyer (2011) described the pappus of $L$. albanicus as denticulate but looking at this character in several specimens collected in Mt. Nëmerçkë, I observed that the pappus can be denticulate and/or plumose as in L. incanus.

Leontodon albanicus is similar to L. hellenicus, from which it differs, in my pers. obs., in the hairness of leaves (L. hellenicus has mainly 6-fid shorter stalked hairs) and phyllaries (L. hellenicus has mainly 2-4-fid hairs, sparse and mainly along the median line, while in L. albanicus hairs are flexuose, long stellate, 2-8-fid (Figs. 1-2), dense all over the surface), and also in the shape of leaves (in L. hellenicus leaves are almost entire to remotely sinuate-dentate) (Table 1).

Comparing to populations in the type locality of L. albanicus, hairness on leaves and bracts in the plants from Mt. Nëmerçkë is denser and their involucres are shorter, probably depending on the altitude.

TABLE 1. Diagnostic differences between L. albanicus, L. hellenicus and L. incanus.

\begin{tabular}{|c|c|c|c|c|}
\hline taxa & habit & leaf shape & leaf hairs & phyllary hairs \\
\hline L. albanicus & up to $20 \mathrm{~cm}$ & sinuate-dentate & $(4-) 8(-9)$ fid & few to dense flexuose mainly along median line $2-8$ fid \\
\hline L. hellenicus & up to $11 \mathrm{~cm}$ & $\begin{array}{l}\text { entire-remotely } \\
\text { sinuate-dentate }\end{array}$ & $(4-) 6(-9)$ fid & few mainly along median line $2-4$ fid \\
\hline L. incanus & $10-35 \mathrm{~cm}$ & entire & $(3-)$ 4-6 & few mainly along median line, simple-2-fid \\
\hline
\end{tabular}

\section{Taxonomic treatment}

Leontodon albanicus (F.K.Meyer) F. Conti, comb. \& stat. nov. (Figs. 1-2)

Basionym:-Leontodon incanus subsp. albanicus Meyer (2011: 170).

Type:-ALBANIA. Mali i Gjer (Mali Gjinezh), zwischen Qafa Gradishtit und Qafa Piloit, ca. 1400 m, 26 June 1959 , F.K.Meyer 3397 (holotype JE, [digital image]!).

Emended description:-Perennial with a taproot and 1 unbranched stem up to ca. $20 \mathrm{~cm}$ tall. Stem ribbed with short stalked 5-9-fid hairs; bracts 0-3. Basal leaves rosulate, 40-130 $\times 5-30 \mathrm{~mm}$, oblanceolate, sinuate-dentate, greyishgreen, with dense, stalked (4-) 8 (-9)-fid hairs on both surfaces. Capitulum solitary. Involucre 13-22 mm, phyllaries linear-lanceolate, in several rows, outer with sparse to dense flexuose long stalked 2-8-fid hairs, pectinate-ciliate with stellate hairs in the upper part. Ligules yellow. Achene 5-6 $\mathrm{mm}$ with minute rigid hairs above, narrowed towards apex. Pappus off-white, 9-11 mm long, denticulate or plumose with a few longer hairs $0.4-0.6 \mathrm{~mm}$. Flowering from end of May to beginning of July, fruiting in July. 


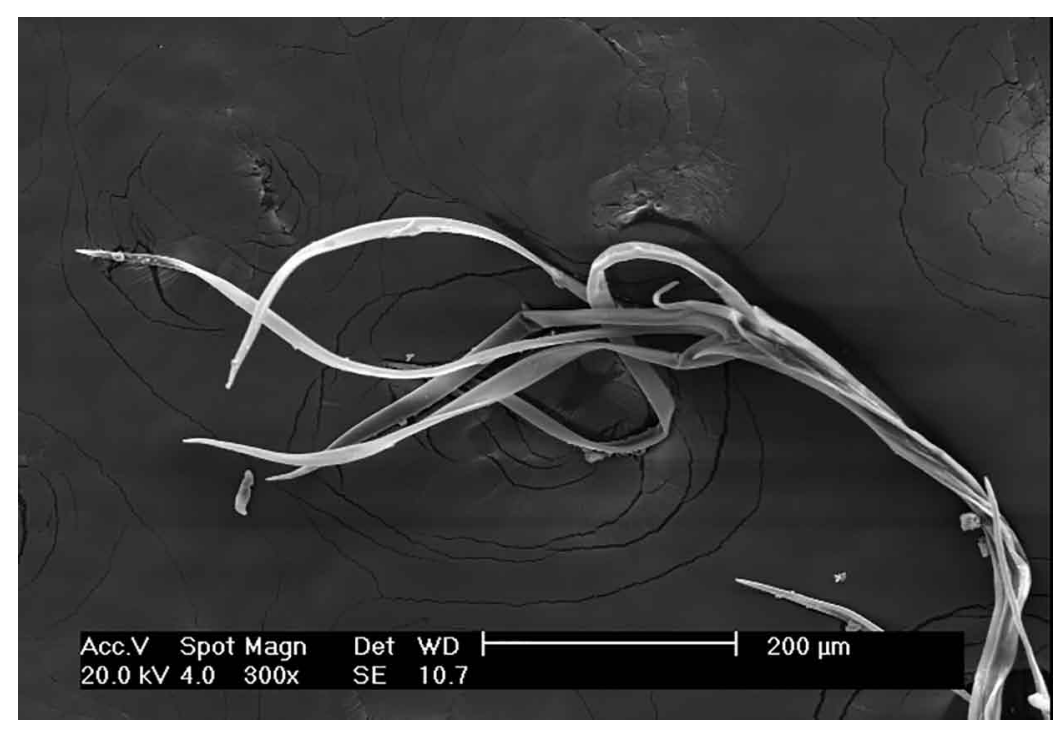

FIGURE 1. Phyllary hairs from a specimen collected on Mt. Nëmerçkë.

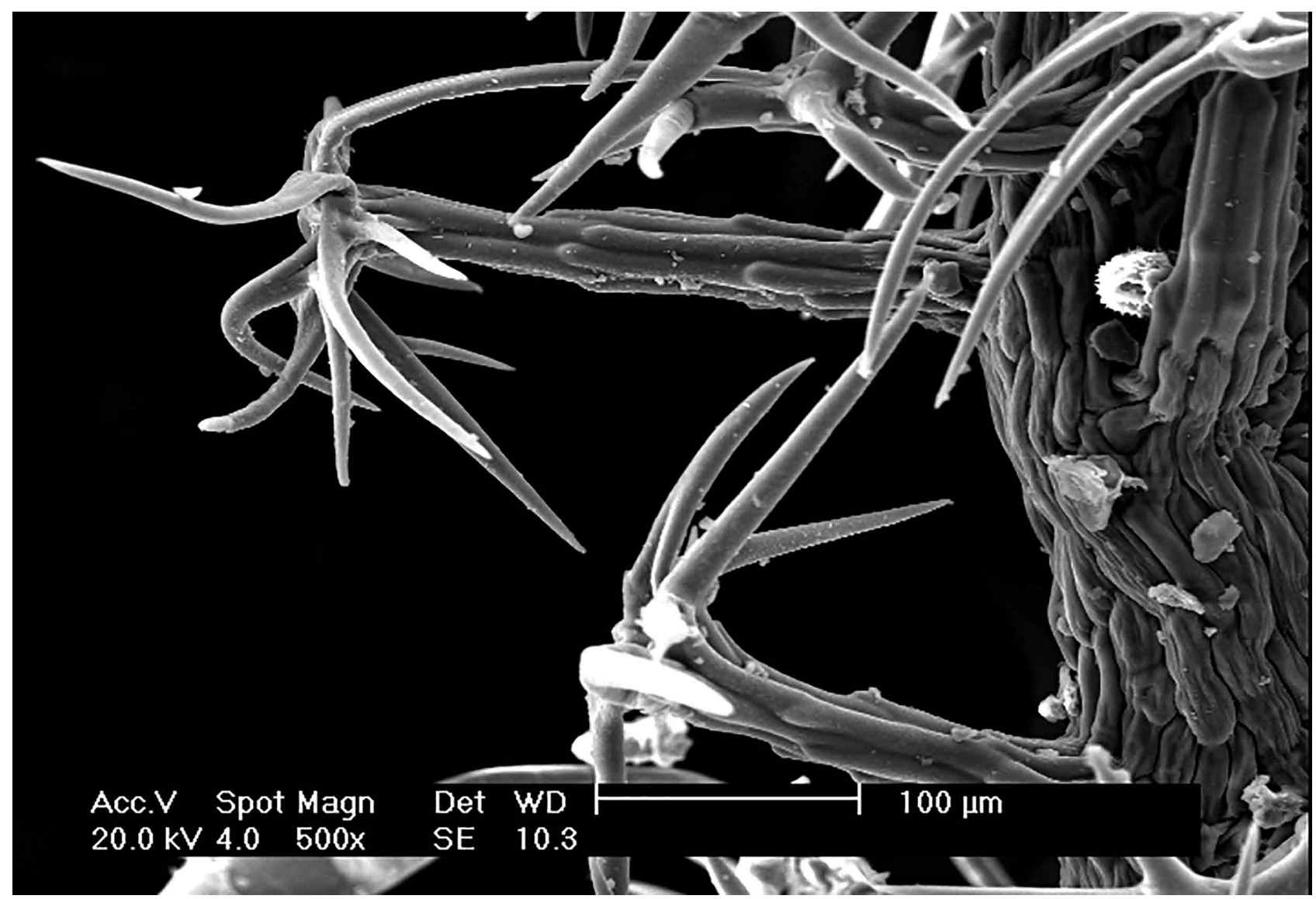

FIGURE 2. Leaf hairs from a specimen collected on Mt. Nëmerçkë.

Distribution and habitat:- The species is endemic to southern Albania and Greece, in a restricted area. It is known from Gjirokastër district (Rrethi i Gjirokastrës) near Fushë Bardhë and Mt. Nëmerçkë.

Additional specimens examined:-ALBANIA. District of Gjirokastër (Rrethi i Gjirokastrës); above the valley of brook "Pirdu" near Fushë Bardhë, between pass Dardhë and Mt Lucë; in deciduos forest, on limestone, $40.09258 \mathrm{~N}$ 19.96774 E, 650 m, 21 May 2011, Z. Barina, H. Mezö \& D. Pifkó 19216 (BP!); idem, 40.0935 N 19.96225 E, 1500 m, 21 May 2011, Z. Barina, H. Mezö \& D. Pifkó 19217 (BP!); Nemercka, near the summit (Maja e Papingut), calcareous scree slopes, $2180 \mathrm{~m}, 40^{\circ} 08^{\prime} 05^{\prime} \mathrm{N}$ 20²4'33'E, 12 July 2012, Conti \& Manilla s.n. (APP Nos. 48886!, 55528!); Tra Poliçan e la vetta del Mt. Nëmerçkë, pendii rupestri e pascoli, 2300 m, 26 June 2015, F. Conti, D. Lakušić, R. Di Pietro, N. Kuzmanović, A. Stinca, S. Durović, I. Janković, R. Pennesi (APP No. 56996!); Mt. Nëmerçkë, circo glaciale 
principale, pendii rupestri, 28 June 2015, F. Conti, R. Di Pietro, A. Stinca, R. Pennesi (APP Nos. 57114!, 57115!, 57118!); Nemërçkë, Dousko, 40.064832 N, 20.479923 E, alt. 1960 m, alpine grasslands, Daphno-Festucetea limestone, 24 June 2015, D.Lakušić, N. Kuzmanović, S. Đurović, I. Janković (BEOU No. 42346). GREECE. Ioannina Nemërçkë, Dousko, 40.06297N, 20.48703E, alpine grasslands, Daphno-Festucetea limestone, 24 June 2015, D.Lakušić, N. Kuzmanović, R. Di Pietro, S. Đurović, I. Janković (APP No. 56301!).

\section{Acknowledgements}

I thank my friends: M. Manilla, D. Lakušić, R. Di Pietro, N. Kuzmanović, A. Stinca, S. Durović, I. Janković and R. Pennesi who travelled with me through Albania, and the Forest Service of Permet (Albania) for the help in the organization of the excursion on the Nemercka Mountains. M. Giammateo (L'Aquila University) is acknowledged for the photos at the SEM, and the curators and directors of the following herbaria for loan of material or providing digital pictures of selected specimens: B (R. Vogt), BP (Z. Barina), JE (H.J. Zündorf, K. Victor), LD (U. Arup, P. Frödén). A. Sennikov and an anonymous referee are acknowledged for the revision of the manuscript.

\section{References}

Ball, J. (1850) Outlines of a Monograph of the genus Leontodon. Annals and Magazine of Natural History [ser. 2] 6: 1-18.

Barina, Z. (Ed.) (2017) Distribution atlas of vascular plants in Albania. Hungarian Natural History Museum, Budapest, 492 pp.

Bartling, F.G. (1820) Ueber einige süddeutsche Pflanzen. Flora 3: 337-352.

Candolle, A.P. de (1838) Prodromus systematis naturalis regni vegetabilis. Vol. 7 (1). Treuttel \& Würz, Paris, Strasbourg, London, 330 pp.

Cassini, H. (1827) Semi-flosculeuses ou Lactucées. In: Cuvier, F. (1827) Dictionnaire des Sciences Naturelles [...], Ed. 2. Vol. 48. F.G.Levrault, Strasbourg \& Paris; Le Normant, Paris, pp. 421-435.

Corbière, L. (1894) Nouvelle flore de Normandie [...]. E. Lanier, Caen, 716 pp.

Endlicher, S.L. (1842) Catalogus horti academici Vindobonensis. Vol. 1. C.Gerold, Wien, 492 pp.

Finch, R.A. \& Sell, P.D. (1976) Leontodon L. In: Tutin, T.G., Heywood, V.H., Burges, N.A., Moore, D.M., Valentine, D.H., Walters, S.M. \& Webb, D.A. (Eds.) Flora Europaea. Vol. 4. Cambridge University Press, Cambridge, pp. 310-315.

Fiori, A. \& Béguinot, A. (1904) Flora analitica d'Italia ossia descrizione delle piante vascolari indigene inselvatichite e largamente coltivate in Italia disposte per quadri analitici. Vol. 3 (2). Tipografia del Seminario, Padova, pp. 273-527.

Gaudin, J.F.A.P. (1830) Flora Helvetica. Vol. 6. Sumptibus Orellii, Fuesslini et Sociorum, Zürich, 400 pp.

Greuter, W. (2006+) Compositae (pro parte majore). In: Greuter, W. \& Raab-Straube, E. von (Eds.) Euro+Med Plantbase - the information resource for Euro-Mediterranean plant diversity. Published on the Internet: http://ww2.bgbm.org/EuroPlusMed/ (accessed 26 March 2018)

Huter, R. (1907) Herbar-Studien. Österreichische Botanische Zeitschrift 57: 111-120. https://doi.org/10.1007/BF01681496

Jahandiez, E. \& Maire, R. (1934) Catalogue des plantes du Maroc, vol. 3. Minerva, Lechevalier éds., Alger, Paris, pp. $559-913$.

Linnaeus, C. (1753) Species Plantarum. L. Salvius, Stockholm, 1200 pp.

Linnaeus, C. (1763) Species Plantarum, ed. 2, vol. 2. Salvius, Stockholm, pp. 785-1684.

Meusel, H. \& Jäger, E. (1992) Vergleichende Chorologie der Zentraleuropeischen Flora, III. Gustav Fischer Verlag, Jena-Stuttgart-New York. 1: ix 333 pp., 2: ix+266 pp.

Meyer, F.K. (2011) Beiträge zur Flora von Albanien. Haussknechtia 15: 1-220.

Phitos, D. (1966) Drei neue Arten aus Griechenland. Österreichische Botanische Zeitschrift 113: 271-272. https://doi.org/10.1007/BF01441039

Pittoni, H. (1974) Behaarung und Chromosomenzahlen sternhaariger Leontodon-Sippen. Phyton (Austria) 16: 165-188.

Reichenbach, C.L. (1832) Flora germanica excursoria [...]. Vol. 2 (2). C.Cnobloch, Lipsia, pp. 435-878.

Roth, A.W. (1830) Manuale botanicum peregrinationibus botanicis accommodatum, Fasc. i [-iii] (classis xvii-xxii). Lipsia [Leipzig], pp. [i], 981-1467.

Samuel, R., Gutermann, W., Stuessy, T.F., Ruas, C.F., Lack, H.-W., Tremetsberger, K., Talavera, S., Hermanowski, B. \& Ehrendorfer, F. (2006) Molecular phylogenetics reveals Leontodon (Asteraceae, Cichorieae) to be diphyletic. American Journal of Botany 93: $1193-1205$ 
https://doi.org/10.3732/ajb.93.8.1193

Schrank von, F.P. (1786) Baiersche Reise. München, 276 pp.

Thiers, B. (2018) Index herbariorum, a global directory of public herbaria and associated staff. New York Botanical Garden's Virtual Herbarium. Available from: http://sweetgum.nybg.org/ih/ (accessed 27 March 2018)

Villars, D. (1779) Prospectus de l'Histoire des plantes de Dauphiné. Imprimerie Royale, Grenoble, 57 pp.

Willdenow, C.L. (1803) Species Plantarum. Vol. 3 (3). G.C. Nauk, Berlin, pp. 1475-2409.

Zidorn, C. (2012) Leontodon and Scorzoneroides (Asteraceae, Cichorieae) in Italy. Plant Biosystems 146 (suppl.): 41-51. https://doi.org/10.1080/11263504.2012.710272 